\title{
Study of the Antimicrobial Activity of Bacteriocins Produced by Lactic Bacteria Isolated from Camel Milk in Southern Algeria
}

\author{
Ammar Touhami Laiche*, Cherifa Khelef and Hinda Daoudi \\ Department of Biology, Faculty of Sciences of Nature and Life, University of El-Oued, El-Oued 39000, Algeria.
}

\begin{abstract}
The objective of this work is the research of lactic bacteria producing antimicrobial substances against harmful germs, the purification of the bacteriocins produced by these bacteria and the determination of their activity spectra. After sampling camel milk in the regions of El Oued (southern Algeria), microbiological and biochemical methods are used to identify the bacteria with antimicrobial activity and the purification of the bacteriocin produced. Nine isolates of lactic acid bacteria have been identified. The dominant species belonging to the genus Lactococcus are: Lactococcus. lactis subsp. lactis, Lactococcus. Lactis subsp. Cremoris, Lactococcus sp, at the genus Pediococci are: Pediococcus acidilactici, at the genus Streptococci are: Streptococcus. Sp, Streptococcus. Thermophilus and the genus Lactobacilli are: Lactobacillus amylophilus. The search for the antagonist substance was performed according to the method of diffusion of the wells. The six lactic strains gave zones of inhibition against pathogenic bacteria. Extraction of the bioactive peptides by the ammonium sulphate precipitation method was carried out. The results obtained show an inhibitory effect of bacteriocin against certain human pathogens (seven bacteria). The greatest inhibition $(8 \mathrm{~mm})$ was observed for bacteriocin of the Lac. lactis subsp. Cremoris against Staphylococcus aureus, then their bactericidal activity against Staphylococcus aureus was studied by the method of minimal inhibitory concentration (MIC). In conclusion, bacteriocin has not only the bactericidal activity, but also the dependent dose of different bacteria.
\end{abstract}

Keywords: Milk, Lactic acid bacteria, Bacteriocin, Purification, Activity spectrum.

\footnotetext{
*Correspondence: laiche-ammar-touhami@univ-eloued.dz; 665595940
}

(Received: 02 January 2019; accepted: 08 February 2019)

Citation: Ammar Touhami Laiche, Cherifa Khelef and Hinda Daoudi, Study of the Antimicrobial Activity of Bactericocins Produced by Lactic Bacteria Isolated from Camel Milk in Southern Algeria, J Pure Appl Microbiol., 2019; 13(2): 1285-1292. doi: 10.22207/ JPAM.13.2.72

C The Author(s) 2019. Open Access. This article is distributed under the terms of the Creative Commons Attribution 4.0 International License which permits unrestricted use, sharing, distribution, and reproduction in any medium, provided you give appropriate credit to the original author(s) and the source, provide a link to the Creative Commons license, and indicate if changes were made. 


\section{INTRODUCTION}

The raw milk of its richness in nutritive substances (proteins, fats, carbohydrates, vitamins) constitutes a favorable environment for the development of the germs. When raised in good conditions, raw milk contains few germs $\left(10^{3}\right.$ germs per $\mathrm{ml}$ ). These are saprophytic-organisms and among them are found lactobacilli, Streptococcus and Leuconostoc (Menad, 2017).

The microbial microflora of raw milk, essentially composed of lactic acid bacteria, plays an important role in the development of the organoleptic characteristics of fermented milk products (fermented milk, cheese) (Boullouf, 2016). On a hygienic level, they slow down the development of undesirable flora and improve the conservation of the food, by lowering the $\mathrm{pH}$ and the production of several metabolites having an anti-microbial effect (Hammi, 2016).

Bio-conservation by lactic acid bacteria is due to their ability to produce several antimicrobial metabolites, such as organic acids (lactic acid, acetic acid), hydrogenperoxide, ethanol, diacetyl, reuterin, carbondioxide and bacteriocins. These antimicrobial substances have the ability to target selectively pathogenic or damaging bacteria, without inhibiting essential bacteria (Hammi, 2016).

The bacterioc in of lactic acid bacteriais an antibacterial polypeptide synthesized in the process of metabolism, it has an antibacterial effect on pathogenic bacteria (Narendrakumar et al., 2017). The interest of the bacteriocins of lactic acid bacteria resides on the one hand in their broad or narrow spectrum antimicrobial effect and on the other hand in their safety for human health, because of their sensitivity to digestive proteases, and their non-toxicity for eukaryotic cells (Ababsa, 2012).
In this context, the objectives of our work are to achieve the isolation, purification and phenotypic characterization of lactic acid bacteria from raw camel milk and the demonstration of the inhibitory activity of isolated lactic acid bacteria against of certain germs of alteration. Thus, the purification of bacteriocins and the determination of their spectrum of activity with respect to these pathogenic bacteria has been carried out.

\section{MATERIALS AND METHODS}

Our study rests on the one hand on the valorization of the technological potentialities of the lactic flora and to evaluate the spectrum of activity of their bacteriocin against certain germs pathogens.

Our samples come from different regions of the wilaya of El Oued (South-East of Algeria). The milking of animals (Dromedary) takes place in the morning, the quantity taken is $250 \mathrm{ml}$ under aseptic conditions to avoid any kind of contamination, this collection serves both a physicochemical and microbiological study. Table 1 shows the characteristics of the breeds from which milk was taken.

\section{Isolation of lactic acid bacteria}

The selective isolation of lactic acid bacteria is done by culture on several media according to the methods described by the International Milk Federation. Seeding is carried out on M17 medium and MRS agar mass, using the decimal dilutions in a sterile solution $(0.85 \%$ $\mathrm{NaCl}, 0.1 \%$ Peptone) (Badis et al., 2005).

After isolation of the colonies, different morphological aspects (size, color, surface, depth) are subcultured on MRS and M17 medium, incubated at 30 or $45^{\circ} \mathrm{C}$ to ensure the purity of the cultures. The purification of the strains on agar medium is done by the method of striations

Table 1. Characteristics of breeds from which different milk was taken

\begin{tabular}{|c|c|c|c|c|c|c|c|}
\hline & & Region & Color & $\begin{array}{c}\text { Age } \\
\text { (years) }\end{array}$ & $\begin{array}{c}\text { Race/ } \\
\text { Population }\end{array}$ & $\begin{array}{l}\text { Sampling } \\
\text { time }\end{array}$ & $\begin{array}{c}\text { Daily } \\
\text { production (L) }\end{array}$ \\
\hline & Sple.1 & El Oeud & Maron & 3 & Targui & $8: 00$ & $3-4$ \\
\hline Camel & Sple. 2 & El Oeud & Maron & 2 & Sahraui & $8: 00$ & $6-7$ \\
\hline \multirow[t]{3}{*}{ Milk } & Sple.3 & El Oeud & sandy & 2.5 & Sahraui & $8: 20$ & $6-7$ \\
\hline & Sple.4 & El Oeud & sandy & 4 & Sahraui & $8: 10$ & $6-8$ \\
\hline & Sple.5 & El Oeud & Maron & 3.5 & Targui & $8: 30$ & $3-4$ \\
\hline
\end{tabular}


followed by a microscopic observation (Lairini et al., 2011).

Identification of purified strains is established for lactic acid bacteria based on morphological and biochemical characters (form, Gram stain, catalase, growth at different temperatures, $\mathrm{NaCl}$ sensitivity, sugar fermentation, $\mathrm{CO}_{2}$ production (Lairini et al., 2011).

\section{Antimicrobial potency study of isolated lactic acid bacteria}

In this part interactions are made between the isolated strains of milk and seven pathogenic bacteria. To carry out the antagonism test, it is necessary to have pre-cultures of the lactic strains and the preculture of the indicator strain (pathogen).

From the MRS and M17 agar slants, we seeded each isolated lactic acid strain in a test tube containing $5 \mathrm{ml}$ of the appropriate broth (MRS or M17). The tube is incubated at 30 and $45^{\circ} \mathrm{C}$ for 18 hours under anaerobic conditions. While the indicator strain was seeded in a serval heart tube and incubated at $37^{\circ} \mathrm{C}$ for 18 hours.

According to the well diffusion method of Barefoot \& Kaenhammer, 1983; a volume of Mueller-Hinton agar medium is poured into sterile Petridishes. After solidification of the medium, the dishes are inoculated on the surface with the suspension of the pathogenic strain $(100 \mu \mathrm{l}, \mathrm{OD}=$ 0.1 to 0.08 ), then wells of $6 \mathrm{~mm}$ in diameter are dugsterilely using a cookie cutter. (Durham bell) on the agar and will be filled with 60 to $80 \mu$ l of filtered and neutralized supernatant, obtained after centrifugation at $4000 \mathrm{rpm}$ for $15 \mathrm{~min}$ of a culture of the lactic strain (in M17 and MRS).

The dishes are incubated at $37^{\circ} \mathrm{C}$. for 24 hours and the antimicrobial activity is revealed by the appearance of zones of inhibition around the wells (Tabak \& Bensoltane, 2011). The diameters of the zones of inhibition appearing around the wells will be measured, the result is positive if the diameter of the zone of inhibition is higher by $2 \mathrm{~mm}$. The measurement of the inhibition diameter $\mathrm{Zi}$ is carried out according to the following formula:

$\mathrm{Zi}$ in $(\mathrm{mm})=$ diameter of the inhibition zone obtained $(\mathrm{mm})$ - diameter of well $(6 \mathrm{~mm})$

\section{Production and purification of bacteriocin}

The bacterial cultures were centrifuged at $5000 \mathrm{xg}$ for $15 \mathrm{~min}$ at $4^{\circ} \mathrm{C}$, the supernatant heated at $80^{\circ} \mathrm{C}$ for $10 \mathrm{~min}$ to degrade the heat-sensitive proteins / peptides and $\mathrm{pH}$ adjusted to 6.5 to neutralize the lactic acid produced by lactic acid bacteria (Makhloufi, 2011).

The supernatant was precipitated at $60 \%$ saturation ammonium sulfate $(37.32 \mathrm{~g}$ ammonium sulfate per $100 \mathrm{ml}$ solution) at $4^{\circ} \mathrm{C}$ and then centrifuged at $9000 \mathrm{xg}$ for $30 \mathrm{~min}$ at $4^{\circ} \mathrm{C}$. The pellet was taken up in $100 \mathrm{ml}$ of water (VWR PROLABO ${ }^{\circledR}$ ) and dialyzed for about $20 \mathrm{~h}$ with dialysis membranes (Spectra-Por ${ }^{\circledR} 3$, MWCO $3.5 \mathrm{kDa}$ ) against ultra-pure water. Once the excess of salts has been removed, the mixture has been lyophilized overnight and stored at $-20^{\circ} \mathrm{C}$. (Mameche 2008, Makhloufi 2011).

Antibacterial activities were assayed against bacterial indicator strains, Listeria innocua clip ATCC 74915, Bacillus cereus, Escherichia coli ATCC 25922, Staphylococcus aureus ATCC 25923, Pseudomonas aeruginosa ATCC 27853, Klebseilla pneumoniae ATCC 700603 and Salmonella sp, using the diffusion method in wells described by Lairini et al., 2014.

Table 2. Morphological characteristics of lactic acid bacteria isolated

\begin{tabular}{|c|c|c|c|}
\hline Groups & $\begin{array}{c}\text { macro } \\
\text { morphology }\end{array}$ & $\begin{array}{c}\text { Micro } \\
\text { Morphology }\end{array}$ & $\mathrm{T}^{\circ} \mathrm{C}$ \\
\hline Streptococci & Round settlements & cocci, Diplocoques & $42-48$ \\
\hline S7 and S8 & Cream white & and in chains & \\
\hline Pediococci & colonies Smooth & Coccis in & 30 \\
\hline S1, S3, and S5 & $\begin{array}{l}\text { rounded, grayish } \\
\text { or whitish }\end{array}$ & tetrads & \\
\hline $\begin{array}{l}\text { Lactococci } \\
\text { S2, S4 and S6 }\end{array}$ & $\begin{array}{l}\text { colonies white, } \\
\text { round or lenticular }\end{array}$ & $\begin{array}{l}\text { cocci, Diplocoques } \\
\text { and in chains }\end{array}$ & 30 \\
\hline Lactobacilli & Small colonies & small & 30 \\
\hline S9 & white, round & Chain sticks & \\
\hline
\end{tabular}


Wells $6 \mathrm{~mm}$ in diameter were drilled cork in the agar. Aliquots $(100 \mu \mathrm{l})$ of bacteriocin solutions were dispensed into the wells and the dishes were pre-incubated at $4^{\circ} \mathrm{C}$. for $2 \mathrm{~h}$ and then incubated for $18 \mathrm{~h}$ at $37^{\circ} \mathrm{C}$. The antagonist activity was expressed as an inhibition zone well surrounding each agar.

The estimation of the MIC for the above organism culture, $100 \mu$ l of log phase cultures were transferred to series of test tubes containing $8 \mathrm{ml}$ of brain heart broth and different concentrations of crude bacteriocin were added to the tubes; 30 , $60,90,120,150,180$ and $210 \mu \mathrm{l}$ and tube without control inoculation, the minimum inhibitory concentration was estimated by measuring the optical density of the culture tubes at $660 \mathrm{~nm}$ using a spectro-photometer (Jaya \& Siva et al., 2018).

\section{RESULTS AND DISCUSSION}

Isolation and identification of lactic acid bacteria

From the milk samples, we obtained 9 isolates, distributed in order of dominance as follows: On $\mathrm{M} 17$ at $30^{\circ} \mathrm{C}$ (6 isolates, $66.67 \%$ )

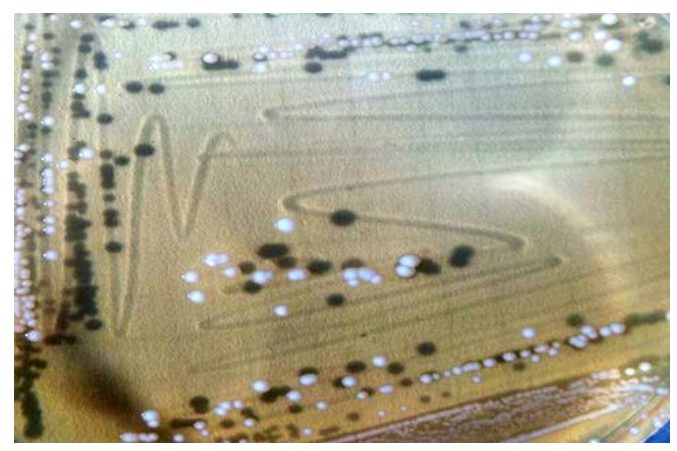

A: Culture of Pediococci on the medium M17 agar

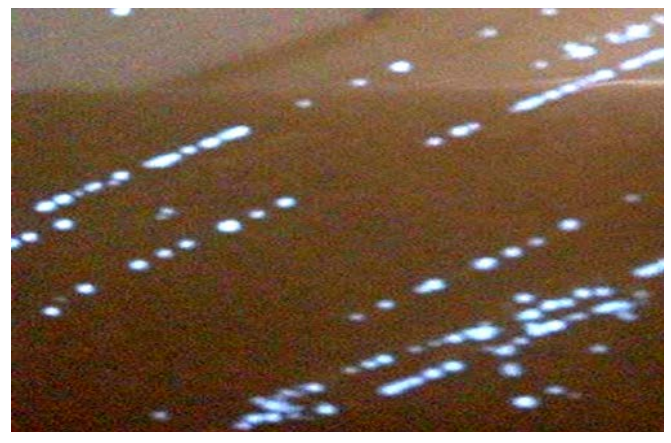

C: Lactobacillus culture on MRS agar medium signified by (S1 to $\mathrm{S} 6$ ), on $\mathrm{M} 17$ at $45^{\circ} \mathrm{C}$ ( 2 isolates, $22.22 \%)$ meant (S7 and $\mathrm{S} 8$ ) and on MRS at $30^{\circ} \mathrm{C}(1$ isolates, $11.11 \%$ ) meant (S9).

The isolates appeared small, circular or lenticular in shape, with a regular and whitish color. On boiling, the strains present a homogeneous disorder that characterizes the group of lactic acid bacteria (Fig.1 and 2). The results of the morphological tests showed that all the strains have a Gram positive and catalase negative. Table 2 allows several remarks.

In addition to morphological testing of bacteria, we used physiological and biochemical tests to determine the genus and species of our collection. The results of these tests are summarized in Table 3. According to this table, our identified strains are: Lactococcus lactis subsp. Lactis (S2), Lactococcus lactis subsp. Cremoris (S4), Pediococcus acidilactici (S5), Lactococcus sp (S6), Streptococcus thermophilus (S8), Lactobacillus amylophilus (S9). Our results do not make it easy to identify strains 1,3 and 7.

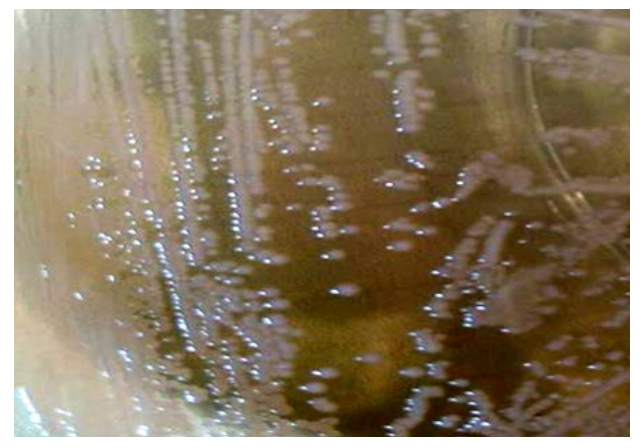

B: Culture of Streptococcus on M17 agar medium

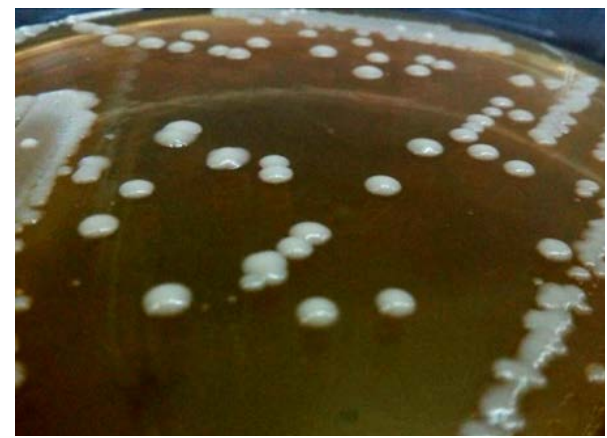

D: Culture Lactococcus on the medium M17 agar

Fig. 1. Macroscopic appearance of lactic strains 

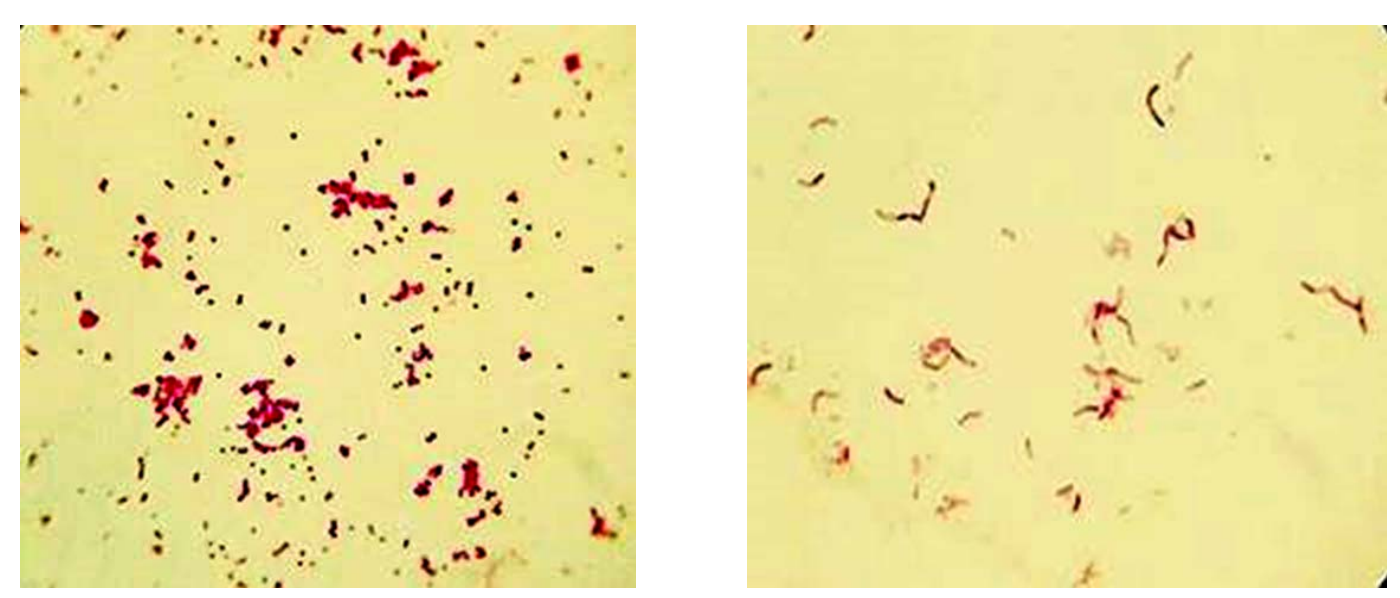

Fig. 2. Microscopic appearance of colonies (Gx100); A: Cocci; B: Bacillus

Antagonist activity of lactic acid bacteria

Strains isolated from raw milk were tested for their ability to inhibit pathogenic bacteria. The results of the interaction obtained, reveal the presence of a clear zone around the strains of lactic acid bacteria of our collections stocked in disks.
The results of the interaction between the lactic acid strains and the pathogenic bacteria: $L$. innocua ATCC 74915, B. cereus, E. coli ATCC 25922, S. aureus ATCC 25923, P. aeruginosa ATCC 27853, K. pneumoniae ATCC 700603 and Salmonella (Fig. 3).

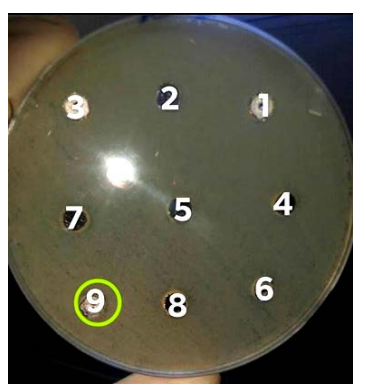

A

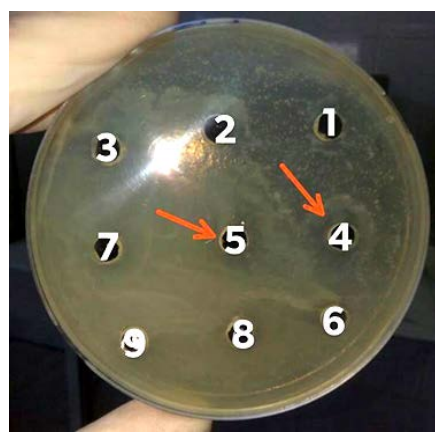

E

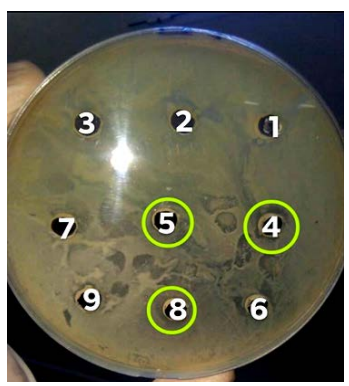

B

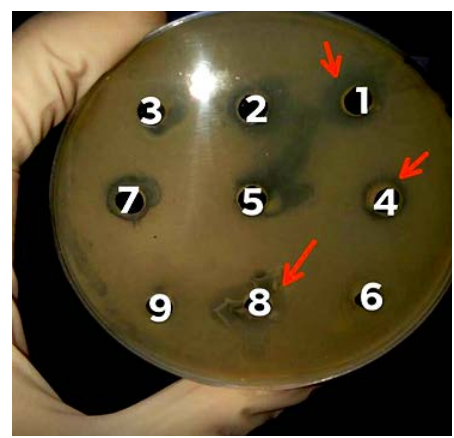

F

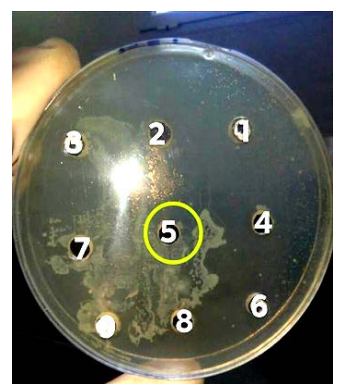

C

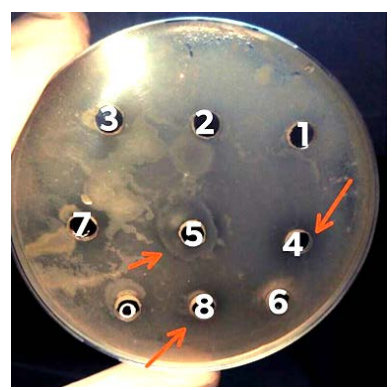

D

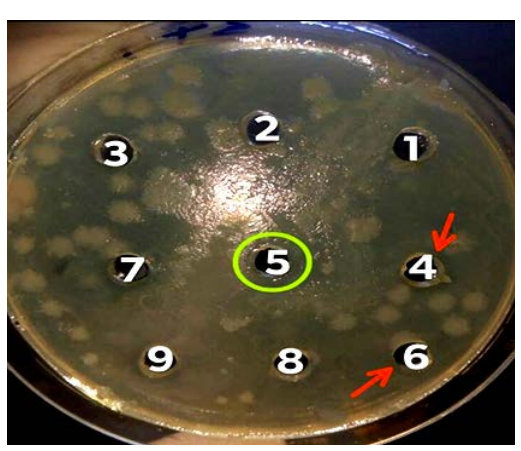

G

Fig. 3. Inhibitions obtained against A: Listeria innocua clip, B: Pseudomonas aeruginosa, C: Klebseilla pneumoniae, D: Escherichia coli, E: Salmonella, F: Bacillus cereus, G: Staphylococcus aureus. 
Table 3. Biochemical and physiological criteria of lactic acid bacteria isolated from camel milk

\begin{tabular}{|c|c|c|c|c|c|c|c|c|c|c|}
\hline & & $\mathrm{S}_{1}$ & $\mathrm{~S}_{2}$ & $\mathrm{~S}_{3}$ & $\mathrm{~S}_{4}$ & $\mathrm{~S}_{5}$ & $\mathrm{~S}_{6}$ & $\mathrm{~S}_{7}$ & $\mathrm{~S}_{8}$ & $\mathrm{~S}_{9}$ \\
\hline ADH & & - & + & - & - & + & - & - & - & - \\
\hline VP & & + & - & + & $\mathrm{V}$ & + & - & - & - & - \\
\hline CIT & & + & + & - & - & - & + & + & + & + \\
\hline $\mathrm{H}_{2} \mathrm{~S}$ & & - & - & - & + & + & - & - & - & - \\
\hline IND & & - & - & - & - & - & - & + & + & + \\
\hline GAZ & & - & - & - & - & - & - & $\mathrm{V}$ & + & _ \\
\hline RES & $v$ & - & - & - & + & $v$ & $\mathrm{~V}$ & $\mathrm{~V}$ & - & \\
\hline \multirow[t]{2}{*}{$\mathrm{T}^{\circ}$} & $40^{\circ} \mathrm{C}$ & - & - & $\mathrm{v}$ & - & - & - & + & + & \\
\hline & $45^{\circ} \mathrm{C}$ & - & - & - & - & - & $v$ & + & + & - \\
\hline \multirow{6}{*}{$\mathrm{pH}$} & 4.2 & - & - & - & - & - & - & & & \\
\hline & 4.5 & & & & & & & - & - & - \\
\hline & 4.8 & - & - & - & - & + & - & & & \\
\hline & 6.5 & & + & & + & & + & - & + & + \\
\hline & 7 & + & + & + & + & + & + & & & \\
\hline & 8 & + & + & + & + & + & + & & & \\
\hline \multirow[t]{4}{*}{$\mathrm{NaCl}$} & $2 \%$ & + & + & + & + & + & + & + & $\mathrm{V}$ & + \\
\hline & $3 \%$ & $\mathrm{v}$ & $\mathrm{V}$ & + & - & + & + & & & \\
\hline & $4 \%$ & $\mathrm{~V}$ & - & + & - & + & $\mathrm{v}$ & + & - & + \\
\hline & $6.5 \%$ & - & - & + & - & + & + & & & \\
\hline CARBO- & GLU & + & + & + & + & + & - & + & + & + \\
\hline \multirow{9}{*}{ HYDRATES } & MAN & + & + & + & + & + & - & + & + & + \\
\hline & RHA & + & - & + & + & + & - & + & + & + \\
\hline & SAC & + & - & + & + & + & - & - & - & + \\
\hline & MEL & + & + & + & + & + & - & + & + & + \\
\hline & Amy & + & - & + & + & + & - & - & - & + \\
\hline & ARA & + & + & + & + & + & - & + & + & + \\
\hline & LAC & + & + & + & + & - & - & - & + & - \\
\hline & INO & - & - & - & + & + & - & - & - & - \\
\hline & SOR & - & - & + & + & + & - & + & + & + \\
\hline
\end{tabular}

+: more than $90 \%$ of positive reactions. - : less than $10 \%$ of positive reactions.V : more than $10 \%$ and less than $90 \%$ of positive reactions. ADH : production of arginine dihydrolase. VP :acetone production. CTR : citrate degradation. RES : heatresistant at $63.5^{\circ} \mathrm{C}$ for $30 \mathrm{~min}$. GAZ : production of gas from glucose.

According to these results, the majority of strains show inhibitory activity, more or less pronounced, on all pathogenic bacteria. These results indicate that our lactic acid bacteria are able to synthesize inhibitory substances with antibacterial activity. All strains do not have the same spectrum of action against pathogenic bacteria. The majority of strains are active on gram-positive bacteria but not all on gramnegative bacteria.

According to these results, the majority of strains show inhibitory activity, more or less pronounced, on all pathogenic bacteria.
These results indicate that our lactic acid bacteria are able to synthesize inhibitory substances with antibacterial activity. All strains do not have the same spectrum of action against pathogenic bacteria. The majority of strains are active on gram-positive bacteria but not all on gram-negative bacteria.

The S4, S5 and S8 producing strains have a broad spectrum of activity against all the indicator strains used. The antibacterial activity of lactic acid strains may be due to the production of several antibacterial agents. Lactic acid and acidification of the medium inhibit several types of bacteria. Also, these strains produce diacetyl, which also has a power of inhibition. $\mathrm{H}_{2} \mathrm{O}_{2}$, released by lactic acid strains, inhibits bacteria that do not have defenses against oxidative stress (eg catalase) (Menad, 2017).

\section{Antagonist effect of purified bacteriocin}

The purified bacteriocin was used to demonstrate their antimicrobial activity against the indicator strains and the result showed that it increased activity against the bacteria including Gram positive used (Fig.4).

The greatest inhibition $(8 \mathrm{~mm})$ was observed for bacteriocin of the Lac strain. lactis subsp. Cremoris (S4) against Staphylococcus aureus, while the smallest with a diameter of ( 2 $\mathrm{mm}$ ) being observed for the bacteriocin of the strain lactococcus sp. The indicator bacterium Staphylococcus aureus can be said to be more sensitive to the bacteriocin of the Lactobacterium. lactis subsp. Cremoris and Lbamylophilus. These results corroborate with the results obtained by (Mami et al., 2010).

While the smallest area is with a diameter of ( $1 \mathrm{~mm}$ ) being observed for bacteriocin strain Str. Thermophilus against Listeria innocua clip. This suggests that LAB's properties make it possible to reduce the number of other undesirable microorganisms in dairy products as well as to play a key role in preserving products intended for human consumption (MAGHNIA, 2011).

\section{Minimum inhibitory concentration (MIC)}

The MIC is the lowest concentration that inhibits any visible growth of a microorganism after 24 hours of incubation in a specific growth medium, they are variable depending on the bacterial species and strains (Fig. 5). 


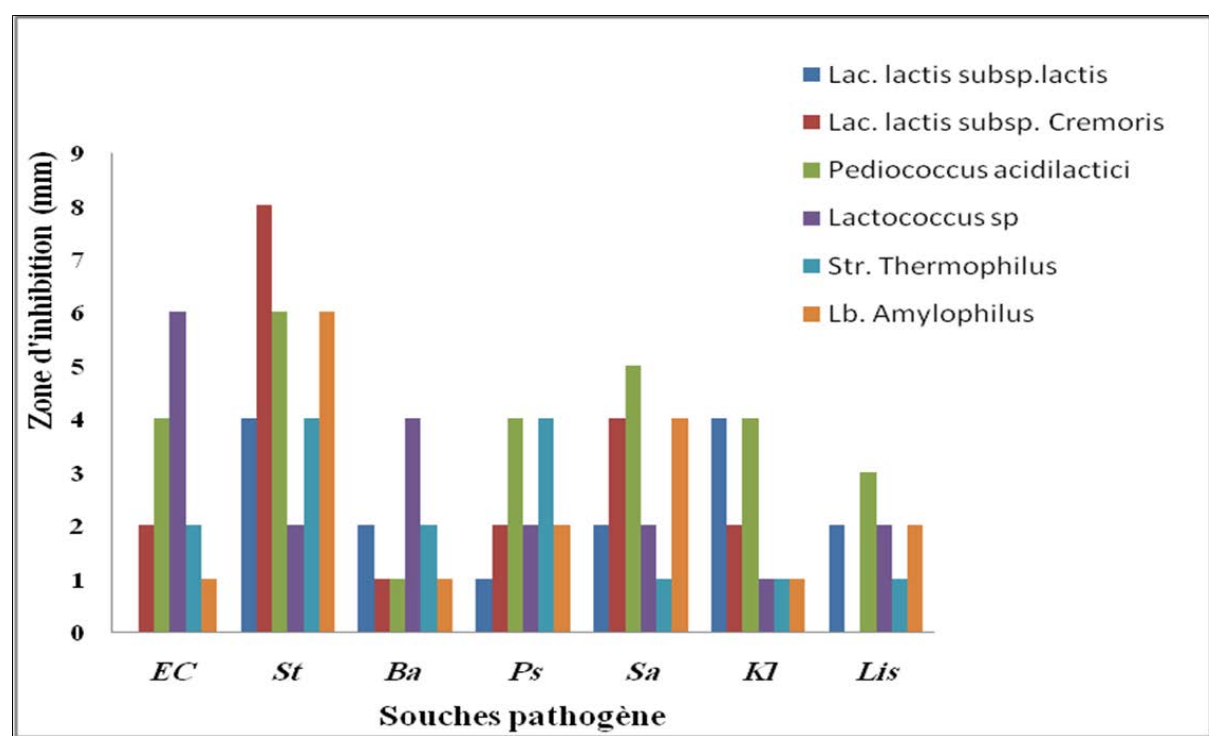

Fig. 4. Effect of producing bacteriocin by lactic acid bacteria against pathogenic strains

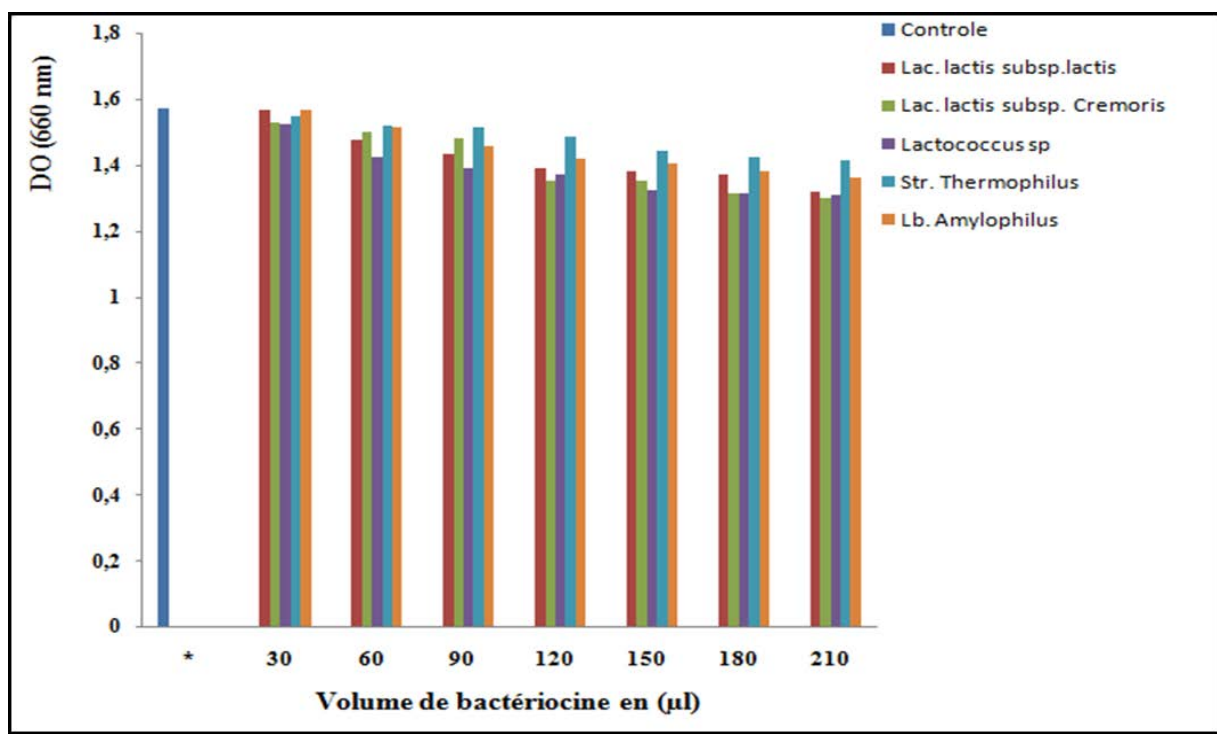

Fig. 5. Optical density of Staphylococcus aureus after treatment with bacteriocins produced by lactic acid bacteria

This suggests that the functioning $L A B$ properties can reduce the number of other undesirable microorganisms in dairy products as well as play a vital role in the preservation of products intended for human consumption (Maghnia, 2011).

The results obtained are very different and show an inhibition against the pathogenic strain Salmonella sp. It is noted that this inhibition is very low because of the low concentration of bacteriocin relative to the concentration of pathogenic bacteria.

On the other hand, Menad (2017) shows that the Lactococcus lactis subsp lactis strains have a total inhibition of the pathogenic strain (Salmonella sp) but for the other dilutions (Lactococcus lactis subsp cremoris) it has been noted that the inhibitory effect is nil whereas the dilutions (Lactobacillus plantarum) have a weak inhibition effect. 


\section{CONCLUSION}

After isolation, purification and biochemical identification of lactic groups; 6 species have been identified (Lactococcus lactis subsp lactis, Lactococcus lactis subsp cremoris, Str. Thermophilus, Lb. Amylophilus, Pediococcus acidilactici, Lactococcus sp). The antagonism test showed the inhibitory effect of our strains on target strains. We have shown that most lactic acid strains produce inhibitory agents against pathogens. The results obtained showed that the strain of Pediococcus acidilactici had more pronounced antibacterial effects than the other strains. The activity of the purified bacteriocins tested on the solid medium and in liquid shows more or less broad activity spectra including, for certain peptides, gram-positive pathogenic bacteria such as S.aureus, B.cereus and Linnocua clip and even Gram-negative such as Salmonella and E. coli. The bacteriocin produced by the Pediococcus acidilactici strain has the broadest spectrum of activity against all the pathogenic bacteria used. The results of the current study revealed that the $S$. aureus strain was sensitive to bacteriocin and showed a response to its concentration.

\section{ACKNOWLEDGEMENTS}

None.

\section{CONFLICT OF INTEREST}

The authors declare that there is no conflict of interest.

\section{AUTHORS' CONTRIBUTION}

All authors have made substantial, direct and intellectual contribution to the work and approved it for publication.

\section{FUNDING}

None

\section{DATA AVAILABILITY}

All datasets generated or analyzed during this study are included in the manuscript.

\section{ETHICS STATEMENT}

This article does not contain any studies with human participants or animals performed by any of the authors.

\section{REFERENCES}

1. Ababsa A. lactic bacteria. Memory magister Unpublished microbiological engineering, University of Setif, Setif. 2012.

2. Badis A., Laouabdia S., Guetarni D., Kihal M., \& Ouzrout R. Phenotypic Characterization of lactic acid bacteria isolated from goat raw milk from two local goat populations "Arabia and Kabyle". Science \& Technology, 2005; 23: 30-37.

3. Hammi I. Isolation and characterization of bacteriocins produced by strains of lactic acid bacteria isolated from Moroccan fermented products and different varieties of French cheese. PhD dissertation. Unpublished analytical chemistry, University of Strasbourg, Strasbourg, 2016.

4. Jayachitra J., \& Sivkumar K. Antimicrobial activity of bacteriocinfrom lactic acid bacteria against food borne bacterial pathogens. International Journal of Current Research in Life Sciences, 2018; 7(4): 1528-1532.

5. Isolation of lactic acid bacteria from traditional Moroccan dairy products and formulation of a fermented milk close to Kefir. Africa Science, 2014; 10(4): 267-277.

6. Maghnia D. Study of the technological potential of lactic acid bacteria isolated from traditional Algerian fermented foods. Unpublished magister microbiology thesis, University of Oran, Oran, 2011.

7. Makhloufi K. Characterization of a bacteriocin produced by a lactic acid bacterium Leuconostoc pseudomesenteroides isolated from boza. PhD Thesis, Microbiology, unpublished biochemistry, Pierre et Marie Curie University Paris, Paris., 2011.

8. Mameche, A. Purification and characterization of bacteriocins produced by isolated native lactic acid bacteria. PhD dissertation unpublished food science, University of Algiers, Algiers. 2008.

9. Mami, A., Hamedi, Am, Henni, J., Kerfouf, A., \& Kihal, M. Anti-bacterial activity of Lactobacillus plantarum isolated from raw goat milk from Algeria with respect to Staphylococcus aureus. Lab technologies, 2010 ; 5(21): 26-33.

10. Menad, N. Antagonist effect of lactic acid bacteria isolated from cow's milk against Salmonella sp. Ph.D. thesis. Microbiologienon published, University of Mostaganem, Mostaganem. 2017.

11. Narendrakumar, G., Sri Gajani,V., \& Preethi Thozhikatu, V. Isolation and Characterization of Bacteriocins like Antimicrobial Compound from Lactobacillus delbrueckii subsplactis. Jordan Journal of Biological Sciences, 2017; 10(4), 221-227.

12. Silva, C., Silva, S., \& Ribeiro, S. Application of bacteriocins and Protective cultures in dairy food preservation. Frontiers in Microbiology, 2018 ; 9:1-15.

13. Tabak, S. and Bensoltane, A. The antagonistic activity of lactic acid bacteria (Streptococcus thermophilus, Bifidobacterium bifidum and Lactobacillus bulgaricus) against the Helicobacter pylori strain responsible for gastroduodenal diseases. Nature \& Technology, 2011; 6:71-79. 